\title{
PENERAPAN MODEL PEMBELAJARAN KOOPERATIF TIPE TAI (TEAM ASSISTED INDIVIDUALIZATION) DALAM PEMBELAJARAN IPA UNTUK MENINGKATKAN AKTIVITAS DAN HASIL BELAJAR SISWA KELAS IX.2 SMP NEGERI 1 BANJARANGKAN TAHUN PELAJARAN 2019/2020
}

\author{
I GEDE MUDIANA \\ SMP Negeri 1 Banjarangkan \\ e-mail : mudianagede1981@gmail.com
}

\begin{abstract}
ABSTRAK
Penelitian ini bertujuan untuk meningkatkan aktivitas belajar dan hasil belajar IPA siswa tentang perkembangbiakan tumbuhan dan hewan secara seksual dan aseksual. Penelitian ini merupakan penelitian tindakan kelas yang terdiri atas 2 siklus yang setiap siklus terdiri atas 4 tahapan, yaitu: 1) perencanaan, 2) tindakan, 3) observasi/evaluasi, dan 4) refleksi. Siklus I dan II masing-masing terdiri dari 3 kali pertemuan. Data aktivitas belajar siswa dikumpulkan dengan menggunakan lembar observasi dan hasil belajar siswa dengan tes. Berdasarkan hasil analisis secara deskriptif menunjukkan 1) terjadi peningkatan aktivitas belajar siswa dengan $\mathrm{KK}=67,75 \%$ berkategori cukup aktif pada siklus I menjadi $\mathrm{KK}=85,10 \%$ berkategori aktif pada siklus II dan 2) terjadi peningkatan hasil belajar siswa dengan rata-rata 75.48 dan $\mathrm{KK}=74 \%$ pada siklus I menjadi rata-rata 80.48 dengan KK $=87 \%$ pada siklus II. Dengan demikian, Penerapan Model Pembelajaran Kooperatif Tipe TAI (Team Assisted Individualization) dalam pembelajaran IPA dapat meningkatkan aktivitas dan hasil belajar siswa kelas IX.2 SMP Negeri 1 Banjarangkan Tahun Pelajaran 2019/2020.
\end{abstract}

Kata kunci : Model Pembelajaran Kooperatif Tipe TAI, Aktivitas Belajar, dan Hasil belajar.

\section{PENDAHULUAN}

Ilmu Pengetahuan Alam (IPA) atau sains berkaitan dengan cara mencari tahu tentang alam secara sistematis, sehingga IPA bukan hanya penguasaan kumpulan pengetahuan yang berupa faktafakta, konsep-konsep, atau prinsip-prinsip saja tetapi juga merupakan suatu proses penemuan (Trianto, 2010:137). Proses pembelajarannya menekankan pada pemberian pengalaman langsung untuk mengembangkan kompetensi agar menjelajahi dan memahami alam sekitar secara ilmiah. Dalam kegiatan pembelajaran peserta didik diharapkan dapat memperoleh pengalaman langsung, sehingga dapat menambah kekuatan untuk mencari, menyimpan, dan menerapkan konsep yang telah dipelajarinya.

Namun kenyataannya, pembelajaran pendidikan IPA substansi sistem reproduksi pada manusia pada siswa kelas IX.2. Setelah dilaksanakan pembelajaran dengan metode diskusi kelompok, ternyata aktivitas belajar siswa masih rendah. Rendahnya aktivitas belajar ditunjukkan dengan bukti bahwa dari 31 siswa hanya 7 (tujuh) siswa atau hanya 23\% yang aktif bertanya, dan hanya 8 (delapan) atau 26\% siswa yang mau mengacungkan tangan untuk menjawab pertanyaan guru. Rendahnya aktivitas siswa ini ternyata berimbas juga pada hasil belajar siswa. Nilai hasil belajar berdasarkan nilai rata-rata ulangan harian substasi sistem reproduksi pada manusia berada pada kategori belum tuntas. Nilai-nilai rata-rata penguasaan konsep peserta didik kelas IX.2 SMP Negeri 1 Banjarangkan tahun pelajaran 2019/2020 adalah sebagai berikut. Nilai tertinggi hasil belajar 85,0 dan terendah 55,0 serta rata-rata pemahaman konsep 72,42 dengan Kriteria Ketuntasan Minimal 74,0 serta Ketuntasan Klasikal (KK) 55\%. Kelas dianggap tuntas jika ketuntasan kelas $\geq$ $85 \%$. Kondisi tersebut menggambarkan terjadinya perbedaan yang sangat tajam antara harapan bahwa idealnya seluruh siswa aktif dan belajar dengan sungguh-sungguh. Kenyataannya siswa yang aktif belajar ditandai dengan kesungguhan menjawab dan bertanya rata-rata $26 \%$. 
Sardiman (2001:20) menyatakan bahwa belajar itu senantiasa merupakan perubahan tingkah laku atau penampilan dengan serangkaian kegiatan Belajar akan lebih baik jika siswa sebagai subyek belajar itu mengalami dan melakukan sendiri. Belajar boleh dikatakan juga sebagai suatu proses interaksi antara diri manusia dengan lingkungannya, yang mungkin berwujud pribadi, fakta, konsep ataupun teori. Proses interaksi itu adalah proses internalisasi dari sesuatu kedalam diri siswa dan di lakukan secara aktif. Hal ini senada dengan pendapatnya Irfandi (2016) yang menyatakan bahwa cara belajar siswa aktif merupakan strategi pembelajaran dimana siswa terlibat secara intelektual maupun emosional sehingga ia betul-betul berperan dan berpartisipasi aktif dalam kegiatan. Tindak lanjut dari internalisasi ini adalah proses sosialisasi atau proses penularan kepada pihak lain, dalam hal ini adalah kepada teman sejawat. Berdasarkan teori tersebut, maka siswa seharusnya melakukan aktivitas belajar untuk mencari tahu, menemukan pengetahuan baru dengan mengalami secara langsung, dan berbagi tentang pengetahuan yang diperolehnya agar tersimpan pada memori jangka panjang.

Menurut Yamin (2007:82), bahwa aktivitas belajar adalah bentuk-bentuk kegiatan yang muncul dalam suatu proses belajar mengajar, baik kegiatan fisik yang mudah diamati maupun kegiatan psikis yang sulit diamati. Dalam kegiatan pembelajaran siswa dituntut untuk selalu aktif, siswa aktif memproses dan mengolah belajarnya secara efektif, siswa harus aktif secara fisik, intelektual, dan emosional. Aktivitas belajar dapat terwujud apabila siswa terlibat belajar secara aktif. Hamalik (2009:179) mendefinisikan belajar aktif sebagai usaha manusia untuk membangun pengetahuan dalam dirinya. Pembelajaran akan menghasilkan suatu perubahan dan peningkatan kemampuan, pengetahuan, dan keterampilan pada diri siswa. Siswa mampu menggali kemampuannya dengan rasa ingin tahunya sehingga interaksi yang terjadi pengalaman dan keinginan untuk mengetahui sesuatu yang baru.

Setelah dilakukan pengamatan dan penelusuran, ternyata keengganan siswa bertanya maupun menjawab pertanyaan, disebabkan oleh beberapa faktor, seperti takut salah, tidak terbiasa berpikir kritis, hanya menerima apa yang mereka dengar, kurang pembiasaan membaca, kurang percaya diri, kurangnya tanggung jawab individu dan kurang pengetahuan dasar atau prayer knowledge. Memperhatikan hasil penelusuran tersebut, peneliti menyimpulkan bahwa permasalahan yang dihadapi siswa adalah kurangnya keberanian dan tanggung jawab individu siswa karena tidak cukup pengetahuan dasar yang dimiliki. Pemecahan masalah yang digunakan adalah melaksanakan pembelajaran dengan Model Kooperatif Tipe TAI (Team Assisted Individualization).

Pembelajaran kooperatif merupakan strategi pengajaran yang melibatkan siswa bekerja secara berkolaboratif untuk mencapai tujuan pembelajaran dan pencapaian kompetensi belajar. Muslimin dkk, 2000 mengemukan bahwa, prinsip dasar dalam pembelajaran kooperatif sebagai berikut. (1) Setiap anggota kelompok (siswa) bertanggung jawab atas segala sesuatu yang dikerjakan dalam kelompoknya. (2) Setiap anggota kelompok (siswa) harus mengetahui bahwa semua anggota kelompok mempunyai tujuan yang sama. (3) Setiap anggota kelompok (siswa) harus membagi tugas dan tanggung jawab yang sama di antara anggota kelompoknya. (4) Setiap anggota kelompok (siswa) berbagi kepemimpinan dan membutuhkan keterampilan untuk belajar bersama selama proses belajarnya. (5) Setiap anggota kelompok (siswa) akan diminta untuk mempertanggungjawabkan secara individual materi yang ditangani dalam kelompok kooperatif. Model pembelajaran kooperatif tipe TAI (Team Assisted Individualization) dipilih untuk meningkatkan aktivitas dan hasil belajar siswa, pada pembelajaran kooperatif tipe TAI (Team Assisted Individualization) yang ditekankan adalah siswa diarahkan untuk menyelesaikan permasalahan yang dihadapi secara individu dan kooperatif. Dengan penerapan model pembelajaran kooperatif tipe TAI (Team Assisted Individualization), akan memberi siswa kesempatan untuk melibatkan segenap kemampuan yang dimilikinya sehingga materi pelajaran dapat dipahami dengan baik (Slavin,1995). Dalam pembelajaran kooperatif tipe TAI (Team Assisted Individualization) siswa dituntut belajar sesuai kemampuannya dan belajar bekerja secara kelompok serta bertanggung 
jawab tentang pengetahuan yang diperolehnya bersama. Selain itu keunggulan pembelajaran kooperatif antara lain: siswa dapat mengembangkan keterampilan sosial dalam memecahkan masalah bersama dan membuat suatu kesimpulan dari permasalahan yang dihadapi. Adanya saling ketergantungan positif, saling membantu dan saling memberikan motivasi sehingga ada interaksi promotif; adanya akuntabilitas individual yang mengukur penguasaan materi pelajaran tiap anggota kelompok, dan kelompok diberi umpan balik tentang hasil belajar para anggotanya sehingga dapat saling mengetahui siapa yang memerlukan bantuan dan siapa yang dapat memberi bantuan.

Model pembelajaran kooperatif tipe TAI (Team Assisted Individualization) diyakini dapat berkontribusi positif meningkatkan aktivitas belajar dan hasil belajar siswa karena tahapan-tahapan pembelajarannya dirancang untuk mengembangkan aktivitas dan cara belajar aktif kreatif. Adapun tahapan model pembelajaran kooperatif tipe TAI (Team Assisted Individualization) adalah sebagai berikut. Pertama siswa mempelajari materi secara individual yang dipersiapkan guru. Tindakan ini memberikan intervensi agar siswa aktif membaca. Kedua setelah materi dikerjakan secara individu kemudian didiskusikan dikelompoknya. Tindakan ini mendorong siswa untuk dapat mengembangkan keterampilan sosial dalam memecahkan masalah, saling membantu, dan saling memberikan motivasi sehingga pembelajaran menjadi menyenangkan. Ketiga, adanya akuntabilitas individual yang mengukur penguasaan materi pelajaran tiap anggota kelompok. Tindakan ini mendorong siswa tiap-tiap kelompok untuk memaksimalkan kemampuan mereka untuk meningkatkan hasil belajarnya. Keempat, pemberian penghargaan kepada kelompok berdasarkan perolehan peningkatan nilai hasil belajar individual dari skor awal ke skor terkini. Hal ini akan dapat meningkatkan motivasi belajar siswa, karena siswa merasa yakin bahwa tujuan mereka tercapai bila siswa lainnya juga mencapai tujuannya. Dengan kata lain, meningkatnya motivasi belajar siswa akan berdampak pula pada meningkatkan aktivitas siswa. yang secara tidak langsung berimbas pada meningkatnya hasil belajar siswa. Hal ini sejalan dengan hasil penelitian yang dilakukan oleh Yuliandari, dkk (2013) yang menyatakan bahwa penerapan model pembelajaran kooperatif tipe TAI (Team Assisted Individualization) dapat meningkatkan hasil belajar siswa.

Tujuan dari penelitian ini ialah untuk mengetahui bagaimana cara meningkatkan aktivitas dan hasil belajar siswa dalam pembelajaran IPA dalam pokok bahasan perkembangbiakan tumbuhan dan hewan secara seksual dan aseksual pada kelas XI.2 SMP Negeri 1 Banjarangkan Tahun Pelajaran 2019/2020.

\section{METODE PENELITIAN}

Prosedur penelitian yang digunakan dalam penelitian ini adalah penelitian tindakan kelas. Rancangan yang digunakan adalah model rancangan yang diadaptasi Stephen Kemmis dan Mc. Taggart (1998) dengan menggunakan dua siklus, dengan masing-masing siklus terdiri dari empat tahapan yaitu: (1) perencanaan, (2) tindakan, (3) observasi dan evaluasi, dan (4) refleksi.

Berikut ini adalah gambar rancangan penelitian tindakan kelas menurut Stephen Kemmis dan Mc. Taggart (1998) terlihat pada gambar 1 di bawah ini. 
Gambar 1. Rancangan penelitian tindakan kelas

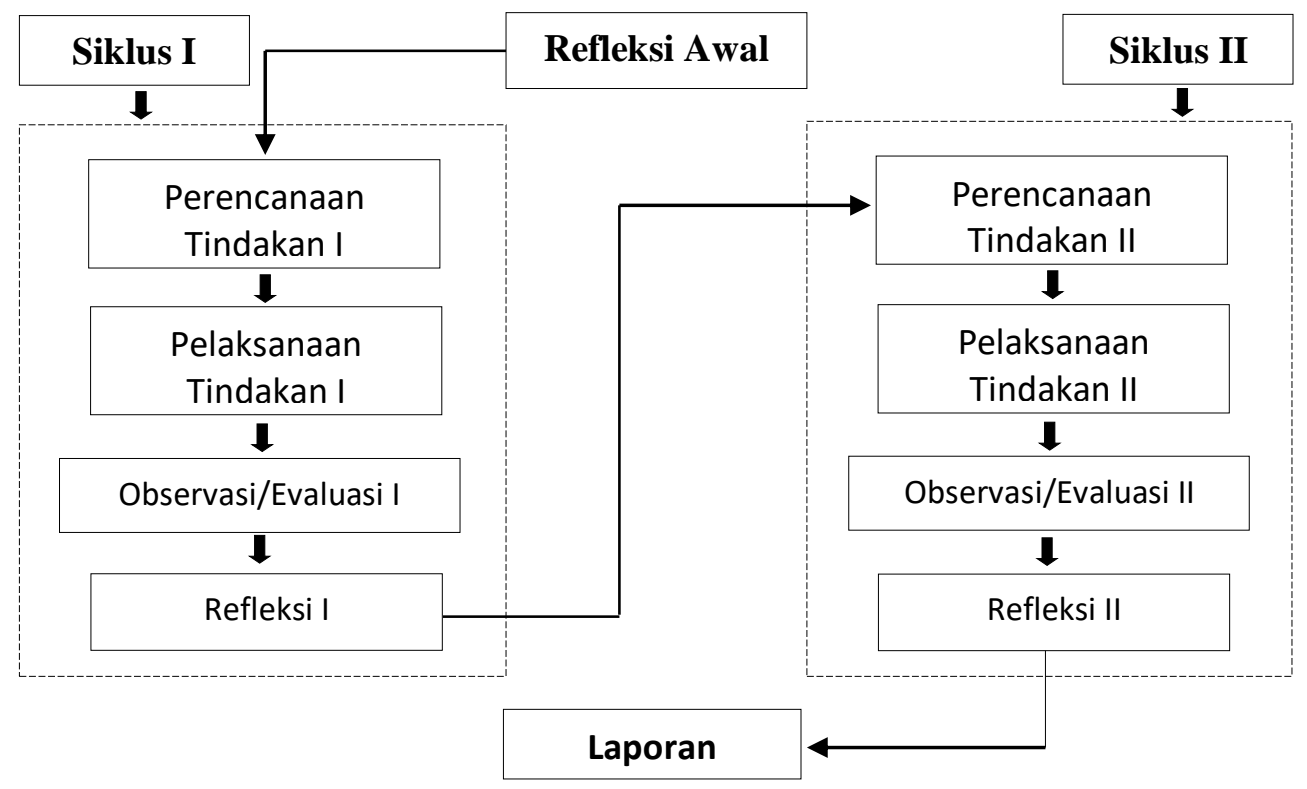

Sebelum pelaksanaan tindakan, peneliti mengadakan refleksi awal untuk mengidentifikasi masalah-masalah yang ada di kelas IX.2 SMP Negeri 1 Banjarangkan. Kegiatan tersebut dilaksanakan pada bulan Agustus 2019. Refleksi awal ini mengacu pada hasil pra siklus dan observasi pembelajaran di kelas, kemudian dilanjutkan dengan siklus I. Pada siklus I sesuai dengan skema yang telah ditetapkan dilakukan beberapa tahapan: tahap (1) perencanaan mencakup merancang RPP sesuai model pembelajaran kooperatif tipe TAI, menyusun materi yang akan dibagikan kepada siswa, membuat soal pre test, membagi siswa kedalam kelompok kecil, membuat soal post test, membuat LKS, dan lembar observasi bagi observer. Tahap (2) melakukan tindakan yang meliputi melakukan pembelajaran tentang perkembangbiakan tumbuhan secara generatif menggunakan model pembelajaran kooperatif tipe TAI pada pertemuan pertama dan perkembangbiakan tumbuhan secara vegetatif pada pertemuan kedua, tahap (3) melakukan pengamatan yang meliputi mengobservasi aktivitas belajar siswa selama proses pembelajaran, mengevaluasi proses pembelajaran, mengevaluasi kendala-kendala serta kesulitan yang ditemukan selama pelaksanaan tindakan siklus I, dan (4) tahap melakukan refleksi tentang hasil aktivitas belajar siswa selama proses pembelajaran dan post tes (tes hasil belajar) pada akhir siklus, perangkat pembelajaran, hasil kerja diskusi kelompok siswa, kegiatan pembelajaran mandiri maupun kelompok. Refleksi juga dilakukan terhadap hasil wawancara dengan siswa tentang kesulitan-kesulitan belajar yang dialami dalam proses pembelajaran dan kendala-kendala yang ditemukan selama pelaksanaan tindakan. Hasil refleksi ini digunakan sebagai dasar memperbaiki dan menyempurnakan perencanaan dan pelaksanaan tindakan pada siklus II.

Pada pelaksanaan siklus II proses pembelajaran yang dilakukan pada siklus ini meliputi: tahap (1) merencanakan rancangan pelaksanaan tindakan lanjutan sebagai hasil refleksi pada siklus I antara lain mengidentifikasi kelemahan-kelemahan pelaksanaan pembelajaran pada siklus I, menyusun materi yang akan dibagikan kepada siswa, membuat soal pre test, membagi siswa kedalam kelompok kecil, membuat soal post test, membuat LKS, dan lembar observasi bagi observer, tahap (2) melakukan tindakan berupa pelaksanaan pembelajaran tentang perkembangbiakan seksual pada hewan pertemuan pertama dan perkembangbiakan aseksual pada 
hewan pertemuan kedua dengan menerapkan model pembelajaran kooperatif tipe TAI, (3) melakukan pengamatan yang meliputi mengobservasi aktivitas belajar siswa selama proses pembelajaran, mengevaluasi proses pembelajaran. Selanjutnya tahap (4) melakukan refleksi tentang hasil aktivitas belajar siswa selama proses pembelajaran dan post tes (tes hasil belajar) pada akhir siklus, perangkat pembelajaran, hasil kerja diskusi kelompok siswa, kegiatan pembelajaran mandiri maupun kelompok.

\section{HASIL DAN PEMBAHASAN}

Penelitian Tindakan Kelas ini dilakukan pada kelas IX.2 SMP Negeri 1 Banjarangkan tahun pelajaran 2019/2020 yang berjumlah 31 orang siswa yang terdiri dari 15 laki-laki dan 16 perempuan dengan menggunakan 2 siklus yakni siklus I dan siklus II serta masing-masing siklus dilakukan sebanyak 3 kali tatap muka, 2 kali untuk PBM dan 1 kali untuk tes.

Berdasarkan hasil pengamatan/observasi selama proses pembelajaran Siklus I dapat dilihat pada Tabel 1.

Tabel 1. Distribusi Aktivitas Belajar Siswa Siklus I

\begin{tabular}{|c|c|c|c|c|}
\hline No. & Kriteria & Kategori & Frekuensi & Persentase $(\%)$ \\
\hline 1. & $86-100$ & $\mathrm{SA}$ & 1 & $3.23 \%$ \\
\hline 2. & $71-85$ & A & 20 & $64.52 \%$ \\
\hline 3. & $56-70$ & $\mathrm{CA}$ & 9 & $29.02 \%$ \\
\hline 4. & $41-55$ & KA & 1 & $3.23 \%$ \\
\hline 5 & $0-40$ & SKA & 0 & $0.00 \%$ \\
\hline \multicolumn{3}{|c|}{ Jumlah } & 31 & $100 \%$ \\
\hline
\end{tabular}

Berdasarkan tabel 1 di atas terlihat aktivitas belajar siswa kelas IX.2 yang mengikuti pembelajaran dengan penerapan model pembelajaran kooperati tipe TAI (Team Assisted Individualization) diperoleh 3,23\% (1 orang) berkategori sangat aktif, 64,52\% berkategori aktif (20 orang), 29,02\% berkategori cukup aktif, dan 3,23\% berkategori kurang aktif (1 orang), dengan ketuntasan klasikal (KK) 67,75\%. Hal ini menunjukkan bahwa selama proses pembelajaran berlangsung hanya sebagian siswa tertentu saja yang memberikan pertanyaan kepada guru ataupun menjawab pertanyaan dan menyelesaikan tugas yang diberikan oleh guru. Siswa yang kurang mampu dan kurang percaya diri masih menunjukkan respon yang pasif dan kurang bertanggung jawab secara individu untuk menyelesaikan tugas yang diberikan. Data hasil belajar siswa pada siklus I dapat dilihat pada tabel 2 di bawah ini.

Tabel 2. Distribusi Nilai Hasil Belajar Siswa Pada Siklus I

\begin{tabular}{|c|l|c|}
\hline No. & \multicolumn{1}{|c|}{ Uraian } & Hasil Siklus I \\
\hline 1. & Nilai Tertinggi & 83 \\
2. & Nilai Terendah & 63 \\
3. & Nilai rata-rata tes hasil belajar & 75,48 \\
4. & Jumlah siswa yang tuntas belajar & 23,00 \\
5. & Jumlah siswa yang tidak tuntas & 08.00 \\
6. & Persentase ketuntasan belajar & $74 \%$ \\
\hline
\end{tabular}


Berdasarkan pada tabel 2 di atas, dapat diketahui bahwa hasil belajar siswa kelas IX.2 yang mengikuti pembelajaran dengan penerapan model pembelajaran kooperati tipe TAI (Team Assisted Individualization) diperoleh nilai rata-rata hasil belajar IPA sebesar 75,48 dan ketuntasan belajar 74\% atau ada 23 siswa dari 31 siswa sudah tuntas belajar. Hasil ini menunjukkan bahwa secara klasikal siswa belum tuntas belajar, karena siswa yang memperoleh nilai $\geq 74(\mathrm{KKM})$ hanya sebesar $74 \%$ lebih kecil dari prosentase ketuntasan yang dikehendaki yaitu sebesar $85 \%$.

Berdasarkan hasil refleksi siklus pertama (siklus I) diketahui bahwa tidak tercapainya ketuntasan aktivitas belajar siswa dipengaruhi oleh beberapa hal yaitu: 1) anak belum terbiasa dalam melaksanakan model pembelajaran, 2) pada saat siswa berdiskusi dengan kelompoknya, komunikasi dan kerja sama antar anggota kelompoknya masih terlihat kurang, 3) kurangnya tanggung jawab individu terutama siswa yang belum menguasai materi, dan berkemampuan kurang, 4) masih terdapat siswa yang pasif mengikuti pembelajaran seperti kurangnya keinginan siswa untuk bertanya dan menjawab pertanyaan guru. Oleh karena itu peneliti merasa perlu melakukan perbaikan tindakan terhadap proses pembelajaran yang telah dilakukan pada siklus I dengan lebih mendekatkan diri kepada siswa, menjelaskan materi secara khusus dan menyuruh siswa yang berkemampuan lebih, dalam anggota kelompoknya untuk membimbing siswa yang berkemampuan kurang sehingga mereka termotivasi untuk belajar lebih giat, di samping itu guru membantu siswa secara intensif terutama siswa yang pasif agar mau mengemukakan pendapat dan berusaha menyelesaikan tugas secara individu terlebih dahulu sebelum didiskusikan dalam kelompok sebagai bentuk tanggung jawab mereka secara individu. Setelah dilakukan tindakan berupa pembelajaran di siklus II maka diperoleh hasil observasi aktivitas dan hasil belajar pada siklus II seperti terlihat dalam tabel 3.

Tabel 3. Distribusi Aktivitas Belajar Siswa Siklus II

\begin{tabular}{|c|c|c|c|c|}
\hline No. & Kriteria & Kategori & Frekuensi & Persentase (\%) \\
\hline 1. & $86-100$ & SA & 3 & $9.68 \%$ \\
\hline 2. & $71-85$ & $\mathrm{~A}$ & 23 & $75.42 \%$ \\
\hline 3. & $56-70$ & $\mathrm{CA}$ & 5 & $14.90 \%$ \\
\hline 4. & $41-55$ & $\mathrm{KA}$ & 0 & $0.00 \%$ \\
\hline 5 & $0-40$ & SKA & 0 & $0.00 \%$ \\
\hline \multicolumn{3}{|c|}{ Jumlah } & 31 & $100 \%$ \\
\hline
\end{tabular}

Berdasarkan tabel 3 di atas terlihat aktivitas belajar siswa kelas IX.2 yang mengikuti pembelajaran dengan penerapan model pembelajaran kooperati tipe TAI (Team Assisted Individualization) diperoleh 9,68\% (3 orang) berkategori sangat aktif, 75,42\% berkategori aktif (23 orang), 14,90\% berkategori cukup aktif, , dengan ketuntasan klasikal (KK) 85,10\%. Hal ini menunjukkan bahwa terjadi peningkatan keaktifan siswa selama proses pembelajaran berlangsung sebesar 20,58\% (dari KK 64,52\% pada sklus 1 menjadi 85,10\% pada siklus II), jumlah siswa yang aktif dalam kegiatan belajar mengajar di kelas semakin banyak. Siswa yang sebelumnya diam saja menjadi berani berkomunikasi dengan teman dalam kelompoknya walau terlihat sedikit ragu dan malu. Di antara mereka mulai berani bertanya kepada guru ketika mengalami kesulitan dalam mengerjakan tugas yang diberikan.dan tanggung jawab secara individu sudah mulai muncul ini terlihat dari anak-anak yang awalnya hanya mengandalkan teman, mulai mengerjakan tugas secara mandiri sebelum didiskusikan dengan teman dalam kelompoknya. Dengan adanya peningkatan keaktifan siswa dalam proses pembelajaran menunjukan bahwa model pembelajaran kooperatif tipe TAI dapat dipakai dalam pembelajaran 
materi perkembangbiakan tumbuhan dan hewan. Selanjutnya data hasil tindakan yang diperoleh pada siklus II berupa data hasil belajar siswa dapat dilihat pada tabel 4 di bawah ini.

Tabel 4. Distribusi Nilai Hasil Belajar Siswa Pada Siklus II

\begin{tabular}{|c|l|c|}
\hline No. & \multicolumn{1}{|c|}{ Uraian } & Hasil Siklus II \\
\hline 1. & Nilai Tertinggi & 90 \\
2. & Nilai Terendah & 71 \\
3. & Nilai rata-rata tes hasil belajar & 80,48 \\
4. & Jumlah siswa yang tuntas belajar & 27,00 \\
5. & Jumlah siswa yang tidak tuntas & 04.00 \\
6. & Persentase ketuntasan belajar & $87 \%$ \\
\hline
\end{tabular}

Berdasarkan pada tabel 4 di atas, dapat diketahui bahwa hasil belajar siswa kelas IX.2 yang mengikuti pembelajaran dengan penerapan model pembelajaran kooperati tipe TAI (Team Assisted Individualization) diperoleh nilai rata-rata hasil belajar IPA sebesar 80,48 dan ketuntasan belajar $87 \%$ atau ada 27 siswa dari 31 siswa sudah tuntas belajar. Hasil ini menunjukkan bahwa secara klasikal siswa sudah tuntas belajar, dan sudah memenuhi syarat karena jumlah siswa yang telah mencapai nilai $\geq 74(\mathrm{KKM})$ sebanyak $87 \%$ dan berada diatas kriteria ketuntasan klasikal 85\%, maka penelitian ini berakhir di siklus kedua 2. Perbandingan hasil belajar siswa pada sikus 1 dengan siklus II ditunjukkan pada Tabel 5 .

Tabel. 5 Perbandingan hasil belajar siswa pada siklus I dan siklus II

\begin{tabular}{|c|l|c|c|}
\hline No. & \multicolumn{1}{|c|}{ Uraian } & Hasil Siklus I & Hasil Siklus II \\
\hline 1. & Nilai Tertinggi & 83 & 90 \\
2. & Nilai Terendah & 63 & 71 \\
3. & Nilai rata-rata tes hasil belajar & 75,48 & 80,48 \\
4. & Jumlah siswa yang tuntas belajar & 23,00 & 27,00 \\
5. & Jumlah siswa yang tidak tuntas & 08.00 & 04.00 \\
6. & Persentase ketuntasan belajar & $74 \%$ & $87 \%$ \\
\hline
\end{tabular}

Gambar 2. Perbandingan Ketuntasan Hasil Belajar Siswa pada Siklus I dan Siklus II

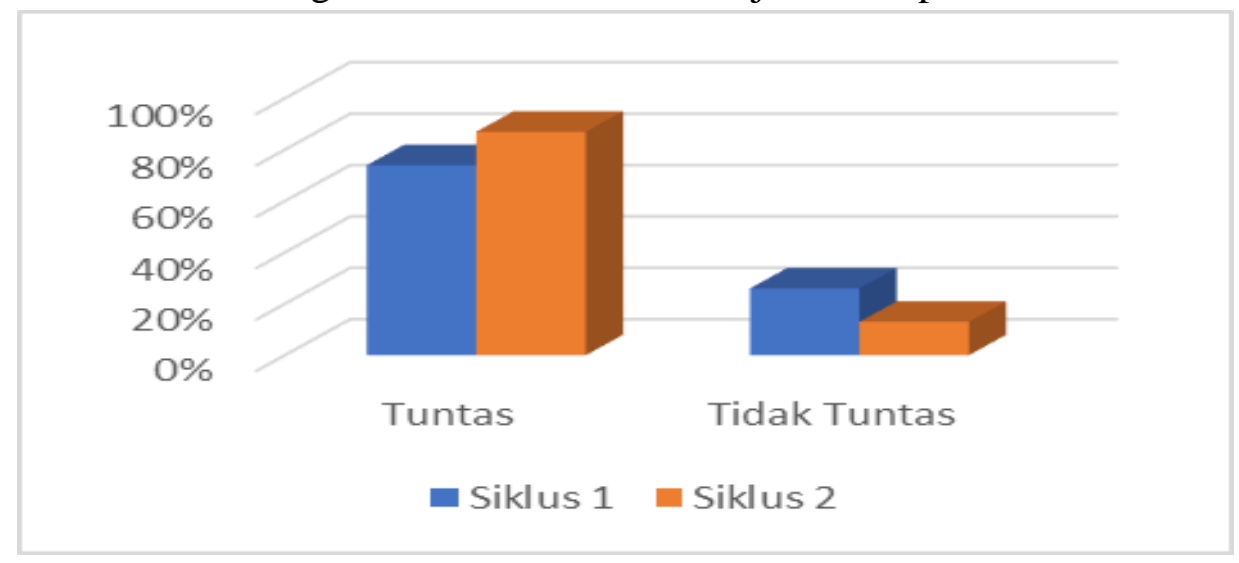

Berdasarkan hasil yang telah diperoleh dalam Penelitian Tindakan Kelas ini serta didukung oleh teori dan peneliti-peneliti lain sebelumnya antara lain: 1) penelitian Pudjawan, dkk 
(2015), penelitian Yuliandari, dkk (2013), dan 3) penelitian Wahyuning, dkk (2013). Dalam penelitiannya, Pudjawan, dkk (2015) menyatakan penerapan model pembelajaran kooperatif tipe Team Assisted Individualization (TAI) berbantuan Lembar Kerja Siswa (LKS) terstruktur dapat meningkatkan hasil belajar Matematika. Hasil penelitian Yuliandari, dkk (2013) menyatakan bahwa penerapan model pembelajaran kooperatif tipe TAI (Team Assisted Individualization) dapat meningkatkan hasil belajar siswa. Penelitian lain yang mendukung adalah penelitian yang dilakukan oleh Wahyuning, dkk (2013), dalam penelitiannya Wahyuning, dkk menyatakan bahwa prestasi belajar matematika antara siswa yang mengikuti model pembelajaran kooperatif tipe "TAI" dengan teknik tutor sebaya lebih baik daripada siswa yang mengikuti model pembelajaran konvensional. Dari tiga hasil penelitian tersebut, maka peneliti meyakini bahwa pembelajaran kooperatif tipe TAI (Team Assisted Individualization) dapat meningkatkan hasil belajar siswa. Persentase siswa kelas IX.2 SMP Negeri 1 Banjarangkan tahun pelajaran 2019/2020 yang tuntas belajar materi perkembangbiakan Tumbuhan dan hewan mencapai 87\% (syarat ketuntasan secara klasikal nilai KKM 85\%). Selain itu model pembelajaran kooperatif tipe TAI (Team Assisted Individualization) juga mampu meningkatkan keaktifan siswa selama proses pembelajaran di kelas. Keaktifan siswa dalam proses pembelajaran materi perkembangbiakan tumbuhan dan hewan kelas IX.2 SMP Negeri 1 Banjarangkan sebesar 85,10\%. Dengan demikian dapat dikatakan penerapan model pembelajaran kooperatif tipe TAI (Team Assisted Individualization) dapat meningkatkan hasil belajar dan keaktifan siswa di kelas. Pembelajaran model kooperatif tipe TAI (Team Assisted Individualization) sangat membantu guru meningkatkan kualitas pembelajaran di kelas terutama dalam mengajarkan materi perkembangan Tumbuhan dan hewan maupun materi lainnya.

\section{PENUTUP}

Sesuai hasil penelitian dan pembahasan, maka dapat dikemukakan bahwa setelah dilakukan tindakan dengan menggunakan penerapan model belajar kooperatif tipe TAI pada siswa kelas IX.2 SMP Negeri 1 Banjarangkan semester ganjil tahun pelajaran 2019/2020 terjadi perubahan keaktifan dan tanggung tanggung jawab siswa dalam menyelesaikan materi tentang perkembangbiakan Tumbuhan dan hewan pada mata pelajaran IPA. Perubahan ini nampak pada hasil observasi maupun pos test yang didapat dari pre tindakan, tindakan pada siklus I, dan tindakan dari siklus II.

Data perkembangan hasil peningkatan aktivitas dan hasil belajar siswa dapat dilihat dari rata-rata perolehan nilai siswa pada masing-masing siklus mengalami peningkatan yakni pada siklus I rata-rata aktivitas siswa 71,60 berkategori cukup aktif dengan ketuntasan klasikal (KK) $67,75 \%$ menjadi rata-rata aktivitas pada siklus II sebesar 76,38 berkategori aktif dengan ketuntasan klasikal $85,10 \%$. Sedangkan untuk hasil belajar rata-rata nilai 75,48 pada siklus I menjadi 80,48 pada siklus II. Persentase ketuntasan belajar juga mengalami peningkatan dari $74 \%$ pada siklus I menjadi $85,10 \%$ pada siklus II.

Dengan hasil penelitian ini, penulis menyarankan kiranya rekan-rekan guru yang lain dapat mencoba menerapkan model pembelajaran kooperatif tipe TAI (Team Assisted Individualization) pada materi lain yang lebih kompeks.

\section{DAFTAR PUSTAKA}

Hamalik, O. 2009. Kurikulum dan Pembelajaran. Jakarta: Bumi Aksara.

Irfandi, R. 2016. Profil Aktivitas Belajar Siswa Kelas VIII-3 pada Penerapan Model Pembelajaran Kooperatif Tipe Student Teams Achivement Divisions (STAD) Materi Getaran dan Gelombang di MTsN Rukoh Banda Aceh. Jurnal Ilmiah Mahasiswa (JIM) Pendidikan 
Fisika. [Online]. 1(4). Tersedia: file:///C:/Users/userPC.user/Downloads/299-530-1-PB.pdf [2 Mei 2018].

K. Arie Wahyuning, M. Candiasa, A. Marhaeni (2013) Pengaruh Model Pembelajaran Kooperatif Tipe "TAI" Dengan Teknik Tutor Sebaya Terhadap Prestasi Belajar Matematika Dengan Pengendalian Kemampuan Penalaran Formal Siswa Kelas VIII SMP Bilingual RSBI Denpasar.

Kemis, W. C., \& Taggart, R. M. 1998. The Action Research Planner. Geedong Victoria: Deakin University.

Muslimin Ibrahim. 2000. Pembelajaran Kooperatif. Surabaya : University Press.

Pudjawan, dkk (2015) Penerapan Model Pembelajaran Kooperatif Tipe Team Assisted Individualization (TAI) Berbantuan Lembar Kerja Siswa (LKS) Terstruktur Untuk Meningkatkan Hasil Belajar Matematika. e-Journal PGSD Universitas Pendidikan Ganesha Jurusan PGSD Vol: 3 No: 1 Tahun: 2015.

Sardiman, A. M. 2006. Interaksi dan Motivasi Belajar Mengajar. Jakarta: Raja Grafindo Persada.

Slavin, Robert. 1995. Cooperative Learning Teori, Research, And Practice. Second Edition. Boston : Allyn And Bacon

Trianto. 2010. Model Pembelajaran Terpadu. Jakarta: Bumi Aksara.

Yamin, N. 2007. Profesionalisme Guru dan Implementasi KTSP. Jakarta: Gaung Persada Press. Yuliandary, dkk (2013) tentang meningkatkan hasil belajar siswa kelas VII B SMP Negeri 1 Tamban pada materi ajar kalor menggunakan model pembelajaran kooperatif tipe TAI (Team Assistted Individualization). 